\title{
Research on Distribution of Residual Stresses of Cold Rolled Sheet Distorted Area Based on ANSYS
}

Wenquan Sun, Jian Shao, Anrui He, Pujun Hao

National Engineering Research Center for Advanced Rolling Technology, University of Science and Technology Beijing. China. E-mail: wqsun18@gmail.com

Based on the value of longitudinal distribution of the residual stresses in the strip with the cold rolled strip in different forms under stress loading, this paper establishes a finite element model. According to the simulation analysis on different stress curve functions and under some coefficient combining conditions of different stress curve functions, it is discovered that the stress acting lengths and the features are completely different under the actions of even-degree and odd-degree stress functions, and under the even-degree function, the residual stresses are distributed evenly at the far end of the strip, and the length location of the point where the residual stresses tends to be stable on the strip are linearly related to the strip width; under the odd-degree function, the residual stresses are distributed linearly in the horizontal direction of the strip while without any changes along the strip length. According to the analysis results of the strip's shear stress, a little strip shear stress is not enough to produce deformation. The result of this paper has profound guiding significance for cold-rolled strip flatness closed-loop control. Only with different control strategies for different flatness deviations after fitting, can the quality of the strip steel flatness be improved more effectively, thereby reducing the impact of the lag in flatness detection on the strip flatness control as far as possible.

Keywords: Cold Rolling, Stress Function, Residual Stress, Finite Element

\section{Acknowledgement}

This work is supported by Doctoral Program Foundation of Institutions of Higher Education of China (No. 20130006120024).

\section{References}

[1] ZHANG, Y., ZHANG, X., HE, Z. (2009). The study of residual stress of cold rolled strip and its influence on plate shape. In: Journal of Plasticity Engineering, Vol. 16, No. 5, pp. 75 - 79. Beijing. China.

[2] HONG, W., ZHAO, X., ZHANG, Y. (2008). Simulation analysis of plastic deformation and residual stress distribution of radial ring rolling. In: Journal of Beijing University of Aeronautics and Astronautics, Vol. 34, No. 9, pp. 1088 - 1091. Beijing.China.

[3] ZHANG, Y. Q., HE, Z. L., ZHANG, X. N. (2009). Three-Dimensional Elastic-Plastic FEM Simulation for Cold Rolling of Plate and Strip. In: Journal of North University of China (Natural Science Edition), Vol. 30, No. 4, pp. 390 - 394. Beijing. China.

[4] JIANG, G. Y., WANG, Y. Q., YAN, X. C. (2010). Analysis on Solution of Residual Stress for Cold Rolling Strip. In: Journal of Iron and Steel Research, Vol. 22, No. 3, pp. 16 - 18. Beijing. China.

[5] PASTOR, M. M., BONADA, J., ROURE, F., et al. (2013). Residual stresses and initial imperfections in non-linear analysis. In: Engineering Structures, Vol. 46, No. 1, pp. 493 - 507. ELSEVIER SCI LTD. England.

[6] JANDERA, M., GARDNER, L., MACHACEK, J. (2008). Residual stresses in cold-rolled stainless steel hollow sections. In: Journal of Constructional Steel Research, Vol. 64, No. 11, pp. 1255 - 1263. ELSEVIER SCI LTD. England.

[7] BEHRAD, K., SIAMAK, S. (2012). Influence of Deformation Path Change on Static Strain Aging of Cold Rolled Steel Strip. In: The International Journal of Advanced Manufacturing Technology, Vol. 61, No. 9, pp. 901 - 906. Springer-Verlag. Germany.

[8] ZENG, J. J., XIONG, Y. B. (2005). Bueking and Residual Stress in Rolling Metal Plate. In: Journal of Plasticity Engineering, Vol. 12, No. 2, pp. 82 - 84. Beijing.China.

[9] MARTINEZ-PEREZ, M. L., BORLADO, F. J., MOMPEAN, C. R., et al. (2005). Measurement and modelling of residual stress in straightened commercial eutectoid steel rods. In: Acta Materials, Vol. 53, No. 16, pp. 4415 4425. Elsevier Ltd. UK.

[10] ZUO, Z. J., FU, L. R., LI, Y. (2011). Measurement of Residual Stress by Cutting Method in Cold Ring Rolling. In: Advanced Materials Research, Vol. 154, pp. 329 - 333. TTP. Switzerland. 
[11] YUAN, H. X., WANG, Y. Q., SHI, Y. J., SHU, G. P., LIAO, D. F. (2014). Experimental study on residual stress distributions in fabricated stainless steel I-sections. In: Journal of Building Structures, Vol. 35, No. 6, pp. $84-92$. Beijing. China.

[12] ZUO, Z. J., YU, W. X., YANG, J. J. (2010). X-Ray Measurement for Residual Stress in Cold Ring Rolling. In: Applied Mechanics and Materials, Vol. 37, pp. 1647 - 1650. TTP. Switzerland.

[13] GUDUR, P. P., DIXIT, U. S. (2008). A Combined Finite Element and Finite Difference Analysis of Cold Flat Rolling. In: Journal of Manufacturing Science and Engineering, Vol. 130, No. 1, pp. 1088 - 1091. ASME-AMER SOC MECHANICAL ENG. USA.

[14] MITAL, D., ZAJAC, J., HATALA, M., MICHALIK, P., DUPLAK, J. (2014). Identification of Internal Residual Stress of Steel after Milling by Ultrasound. In: Manufacturing Technology, Vol. 14, No. 4, pp. 573 - 578 . Usti nad Labem. Czech Republic.

[15] STANČEKOVÁ, D., ŠEMCER, J., DERBAS. M., KURŇAVA, T. (2013). Methods of Measuring of Residual Stresses and Evaluation of Residual State of Functional Surfaces by X-Ray Diffractometric Methods. In: Manufacturing Technology, Vol. 13, No. 4, pp. 574 - 552. Usti nad Labem. Czech Republic.

[16] DE GIORGI, M. (2011). Residual Stress Evolution in Cold-rolled Steels. In: International Journal of Fatigue, Vol. 33, No. 3, pp. 507 - 512. ELSEVIER SCI LTD. England.

[17] LI, B., ZHANG, Q. D., ZHANG, X. F. (2014). Two-dimensional Numerical Simulation of Residual Stress of Strip in Temper Rolling Process. In: Steel Rolling, Vol. 31, No. 1, pp. 14 - 18. Beijing. China.

[18] NOVÁK, P., MEŠKO, J., ZMINDÁK, M. (2013). Finite Element Implementation of Multi-Pass Fillet Weld with Phase Changes. In: Manufacturing Technology, Vol. 13, No. 1, pp. 79 - 85. Usti nad Labem. Czech Republic.

[19] GALANIS, N. I., MARKOPOULOS, A. P., GIANNAKOPOULOS, I. D., MANOLAKOS, D. E. (2013). Manufacturing of Femoral Heads from Ti-6Al-4V Alloy with High Speed Machining 3D Finite Element Modelling and Experimental Validation. In: Manufacturing Technology, Vol. 13, No. 4, pp. 437 - 444. Usti nad Labem. Czech Republic. 